\title{
Beta lactam hypersensitivities
}

\author{
Marie Eliane* Azoury $^{1 *}$, Noémie* Scornet ${ }^{2}$, Stéphanie Delluc ${ }^{3}$, Sandrine Delarue-Cochin ${ }^{2}$, Cathy Nhim ${ }^{1}$, \\ Bernard Maillere ${ }^{4}$, Richard Weaver ${ }^{5}$, Nancy Claude ${ }^{5}$, Delphine Joseph ${ }^{2}$, Marc Pallardy ${ }^{1}$ \\ From 6th Drug Hypersensitivity Meeting (DHM 6) \\ Bern, Switzerland. 9-12 April 2014
}

\section{Background}

Allergic reactions to drugs are often unpredictable and can lead to serious side effects such as anaphylactic shock. According to the hapten hypothesis, any drug with a molecular weight lower than 1000 daltons cannot induce an immune response by itself and must be bound to a protein. Antigen presenting cells, such as dendritic cells (DC), internalize hapten-protein conjugates and digest them into peptides bound with the drug. The latter are then presented on HLA molecules to drug-specific $\mathrm{T}$ cells inducing specific-drug immune response. Knowing that drugs provoke IgE mediated hypersensitivity reactions in treated patients, the CD4+ T-cell response to benzylpenicillin (BP) was investigated. The objectives of this study were to evaluate the frequency of naïve CD4+ T cells specific to $\mathrm{BP}$ and to identify BP-haptenized peptides responsible for T lymphocyte activation.

\section{Method}

Since BP is known to bind covalently to proteins, such as Human Serum Albumin (HSA), HSA-BP bio-conjugates were synthesized at basic $\mathrm{pH}(\mathrm{pH}=10.8)$. Seventeen BP binding-sites on HSA were then identified using massspectrometry, and $12 \mathrm{BP}$-haptenized peptides of $15 \mathrm{mer}$ long potentially presented to T-cells via HLA class II molecules were identified and synthetized. Naïve CD4+ $\mathrm{T}$ cells from non-allergic donors were stimulated once a week with autologous DC loaded with HSA-BP or with peptide-BP to amplify respectively HSA-BP- or peptideBP-specific T cells. Activation of specific CD4+ T cells was detected using interferon- EliSpot and their frequency was calculated using the Poisson distribution law.

\section{Results}

The results of the CD4+ T-cell response to $\mathrm{BP}$ were as follows:

${ }^{1}$ UniverSud, Inserm UMR996, France

Full list of author information is available at the end of the article
- Detection of HSA-BP-specific CD4+ T cells in 12 out of 13 tested donors with a mean frequency of 0.26 cells/million of circulating CD4+ T cells

- Identification of 17 binding sites of BP on HSA

- Specific naïve CD4+ T cells recognized at least 3 specific peptides, from HSA, haptenized by BP.

\section{Conclusion}

This study showed the capacity of HSA-BP to be recognized by naïve T-cells from multiple healthy donors irrespective of their HLA typing and the possibility to identify BP-haptenized peptides involved in the allergic reaction to $\mathrm{BP}$.

\section{Authors' details}

'UniverSud, Inserm UMR996, France. ²UniverSud, UMR CNRS8076, France. ${ }^{3}$ Platine Pharma service, France. ${ }^{4} \mathrm{CEA}$, IbiTecS, Simopro, France. ${ }^{5}$ Institut de Recherches Internationales Servier, France.

Published: 18 July 2014

\section{doi:10.1186/2045-7022-4-S3-P65}

Cite this article as: Azoury et al:: Beta lactam hypersensitivities. Clinical and Translational Allergy 2014 4(Suppl 3):P65

\section{Submit your next manuscript to BioMed Central} and take full advantage of:

- Convenient online submission

- Thorough peer review

- No space constraints or color figure charges

- Immediate publication on acceptance

- Inclusion in PubMed, CAS, Scopus and Google Scholar

- Research which is freely available for redistribution

Submit your manuscript at www.biomedcentral.com/submit

\section{() Biomed Central}

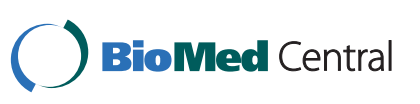

